ISSN: 2146-3042

DOI: $10.25095 /$ mufad.944461

\title{
Katılım Bankalarında Kârlılığa Etki Eden Faktörlerin Tespiti İçin Panel Veri Analizi Uygulaması*
}

\author{
Cengiz YILMAZ** \\ Ersan ÖZGÜR***
}

\section{ÖZET}

Türkiye'de "Özel Finans Kurumu” ismi ile katılım bankacılı̆̆ ilk olarak 1984 yılında faaliyet göstermeye başlamışıır. Bu çalışmada, katılım bankalarında kârlılı̆̆a etki eden faktörlerin panel veri analizi ile tespit edilmesi amaçlanmıştır. Çalışmada, 2015 - 2019 yılları arasında 5 yıllık döneme ilişkin veriler kullanılarak panel veri analizi gerçekleştirilmiştir. Analizde, net dönem kârı (zararl)/toplam aktifler bağımlı değişkenine etki eden içsel ve dışsal faktörler değerlendirilmiștir. Uygulanan panel veri analizi sonucunda; modelin bağımsız değișkeni \%86 düzeyinde açıklama gücü olduğu, aktif kârlılı̆̆ ile anlamlı ilişkisi bulunan (1) sermaye yeterlilik oranında \%1 artış aktif kârlılıkta \%0.13 oranında, (2) kullandırllan fonlar/toplam aktifler oranında \%1 artış aktif kârlılıkta \%2.91 oranında negatif etkili olabileceği belirlenmiştir. Elde edilen bulgular yönünden; sermaye yeterlilik oranının aktif kârlılı̆̆a negatif yönlü etkisinin olması risk unsurlarının minimize edilmesi ihtiyacı dolayısıyla bu durumun kârlılığa olumsuz etki etmiş olabileceği, kullandırılan fonlar/toplam aktifler oranının katılım bankalarında kârlılığa negatif yönde yansıması ise; katılım bankalarının fon kullandırma oranında artış ile takipteki kredilerin artışının söz konusu olabileceği bunun da kârlılı̆̆a olumsuz etki etmiş olabileceği değerlendirilmiştir.

Anahtar Kelimeler: Katılım Bankacılı̆̆ı, Kârlılık, Panel Veri Analizi

JEL Sinıflandırması: G17, G21

\begin{abstract}
Determining the Factors Affecting Profitability in Partıcipation Banks: A Panel Data Investigation

\section{ABSTRACT}

Participation banking started to operate in Turkey in 1984 under the name of "Private Finance Institution". This study, it is aimed to determine the factors affecting profitability in participation banks by panel data analysis. Panel data analysis is used by using 5-years of data belong to 2015 and 2019. The internal and external factors affecting the net profit (loss) / total assets dependent variable are evaluated. Results reveal that (1) 1\% increase in capital adequacy ratio, which has a significant relationship with return on assets, affects return on assets by $0.13 \%$. (2) $1 \%$ increase in the funds used / total assets ratio is effective in return on assets by $2.91 \%$. In terms of findings obtained; the negative impact of the capital adequacy ratio on active profitability might have negatively affected the profitability due to the need to minimize the risk factors, and the negative reflection of the funds used/total assets ratio on the profitability in participation banks; it has been evaluated that the increase in the fund lending rate of participation banks with the increase in non-performing loans might have a negative affect on profitability.
\end{abstract}

Keywords: Participation Banking, Profitability, Panel Data Analysis.

Jel Classification: G17, G21

\footnotetext{
* Makale Gönderim Tarihi: 31.05.2021, Makale Kabul Tarihi: 20.08.2021 , Makale Türü: Nicel Analiz

** Doç. Dr., Afyon Kocatepe Üniversitesi, İktisadi ve İdari Bilimler Fakültesi, İşletme Bölümü ylmzcc@yahoo.com, ORCID: 0000-0002-0581-2804

*** Dr., Türkiye Büyük Millet Meclisi, Kamu Denetçiliği Kurumu, ersanozgur@yahoo.com, ORCID: 0000-00026165-4556
} 


\section{GíRiş}

Katılım bankaları; bireysel ve kurumsal fon ihtiyaçlarının karşılanması, tasarrufların değerlendirmesi ve bankacılık hizmetlerinden yararlanılması maksadıyla kurulan ve sunulan bankacılık hizmetleri ile ilgili olarak faiz almayan ve faiz vermeyen bankalar olarak açıklanabilir. Literatürde genel olarak, İslâmi bankacılık olarak isimlendirilen Türkiye uygulamasındaki ismiyle katılım bankacılığını konvansiyonel bankacılıktan ayıran en önemli özelliği; İslâm dinine göre faizin haram olması dolayısıyla ekonomik sistemin işleyişinde faiz uygulamasını reddetmesidir. Faizsiz bankacılık uygulayan katılım bankaları; "paranın bir mal değil, bir finansman ölçüsü olmasına ve emeğini ortaya koyan ile sermayesini ortaya koyanın, kâr veya zarara birlikte katlanması" anlayışına dayanmaktadır (Alpun, 2017:37).

1940’l1 yılların sonlarından itibaren İslâmi bankacılık alanında akademik çalışmalarla gelişmeler kaydedilmiştir. Özellikle Pakistanlı akademisyenler tarafından yapılan teorik çalışmalarla faizin yer almadığı bankacılık sisteminin uygulanabileceği yönünde fikir birliği oluşmuştur. Faizsiz bankacılık ile ilgili Pakistanlı iktisatçı Muhammed Uzair 1955 yılında "An Outline of Interestless Banking" konusunda yaptığı araştırmada, faizsiz bankacılık hususunda fikirleri değerlendirmiştir. $\mathrm{Bu}$ fikirler, uzun zaman akademik platformda tartışılmıştır. Faizsiz sistemde kurulan ilk banka, 1963 yılında Mısır'da Nil kenarında MitGhamr'da, Suudi Arabistan Kralı Faysal'ın yardımıyla, tekstil endüstrisini finanse etmek için kurulmuştur. Bu banka, Almanya'da daha önce uygulanmış bulunan tasarruf bankalarından esinlenerek kurgulanmıştır. Kısa bir zamanda 9 şubeli bir banka şeklinde hizmet etmiş olmakla birlikte değişik sebeplerle sürdürülebilir olamamış ve 1977 yılında kapanmak zorunda kalmıştır (Özgür, 2007:42-43).

Türkiye'de faizsiz sistemde bankaların kurulması ise, 1970'li yıllarda dünyada yaşanan petrol krizi dolayısıyla petrol üreticisi İslâm ülkelerinde toplanan büyük miktardaki sermayenin faizsiz bankacılık uygulaması ile Türkiye'ye çekilmesine yönelik çalışmalara dayanmaktadır. Ayrıca faizsiz bankacılık ile Türkiye'de faize karşı hassas olan kişilerin atıl durumdaki fonlarının ülke ekonomisine kazandırılması da hedeflenmiştir (Erdaş, 2015:83).

Katılım bankacılığının Türkiye'de “Özel Finans Kurumu” ismi ile uygulaması ilk olarak 1984 yılında başlamıştır. 16.12.1983 tarihli Bakanlar Kurulu Kararı'na dayalı olarak Albaraka Türk Özel Finans Kurumu 21.01.1985 tarihi itibariyle T.C. Merkez Bankası'ndan faaliyet izni almak suretiyle resmen hizmete başlamıştır. "Özel Finans Kurumu” şeklinde isimlendirilen faizsiz kurumlar, 19.10.2005 tarih ve 5411 sayılı Bankacılık Kanunu'nda yapılan değişiklik ile "Katılım Bankaları” olarak değiştirilmiştir (TKBB, 2019).

Katılım bankaları faaliyetleri itibariyle ticari ve sınai üretim için ihtiyaç duyulan hammadde, yarı mamul veya mamul madde sağlanması için fon kullandırmaktadır. Katılım bankalarında; faizli işlemler, belirsizlik içeren ve aşırı riskli ve spekülatif işlemler uygulanmamaktadır. Ayrıca, alkollü içecek, domuz eti ve ürünleri ve kumar-şans oyunları gibi İslâmi açıdan yasak olan konularda işlem yapılmamaktadır (TKBB, 2021).

Katılım bankaları konvansiyonel bankalardan işleyiş itibariyle farklıdır. Ancak tüm bankalar varlığını sürdürebilmek ve olası krizlerden düşük düzeyde etkilenmek için rekabet halindedir. Rekabet neticesinde güçlü bankalar varlığını devam ettirmekte zayıf bankalar ise iflas noktasına gelebilmektedir. Rekabet bir yönüyle kârlılık ile ilişkilendirilebilir. Bu nedenle 
katılım bankalarında kârlılık ve kârlılığa etki eden faktörlerin tespit edilmesi önem arz etmektedir (Esmer ve Bağc1, 2016:18)

Araştırma çalışması ile katılım bankalarının kârlılığına etki eden içsel ve dışsal faktörlerin belirlenmesi amaçlanmıştır. Bu doğrultuda araştırma çalışmasında panel veri analizi uygulanmıştır.

Zaman boyutuna sahip yatay kesit verileri kullanılmak suretiyle oluşturulan panel verilerle kurulan modeller ile ekonomik ilişkiler tahmin edilebilmektedir. Bu uygulama "panel veri analizi" olarak adlandırılmaktadır (Tatoğlu, 2020:6).

$\mathrm{Bu}$ çalışmada halen faaliyette olan 6 katılım bankasından 5'i karar birimi olarak alınmıştır. Bu bankalardan 2'si 2015 yılında kurulmuş olması dolayısıyla analiz başlangıç yılı 2015 yılı olarak değerlendirilmiştir. 2015 yılı öncesi sadece 3 katılım bankası değerlendirmeye alınabildiğinden böyle bir tercihte bulunulmuştur.

$\mathrm{Bu}$ çalışmada, ilk olarak katılım bankalarının genel durumu değerlendirilmiş, ardından bankacılık sektöründe kârlılığına etki eden faktörlerin belirlenmesi uygulamasına ilişkin literatür bilgisine yer verilmiş, sonra araştırmanın amacı ve kapsamı belirtilmiş, daha sonra araştırmanın yöntemi olan panel veri analizi ve modeli hakkında bilgiler verilmiş ve son olarak araştırmanın uygulaması gerçekleştirilmek suretiyle elde edilen bulgular değerlendirilmiştir.

\section{KATILIM BANKALARININ GENEL DURUMU}

Dünyada faizsiz bankalar olarak bilinen bankalar Türkiye'de Katılım Bankası şeklinde ifade edilmektedir. Faizsiz sistemle çalışan katılım bankaları, kâr ve zarara katılma esasına göre fon toplayıp; ticaret, ortaklık ve finansal kiralama yöntemleriyle fon kullandırmaktadır. Katılım bankaları İslami iktisat sistemini kullanırlar ve Türkiye Katılım Bankalar Birliği (TKBB)'ne bağlı olarak faaliyet gösterirler (Esmer ve Bağc1, 2016:18) Katılım bankalarının 2015-2019 yılları arasındaki gelişimi aşağıdaki şekillerde verilmektedir.

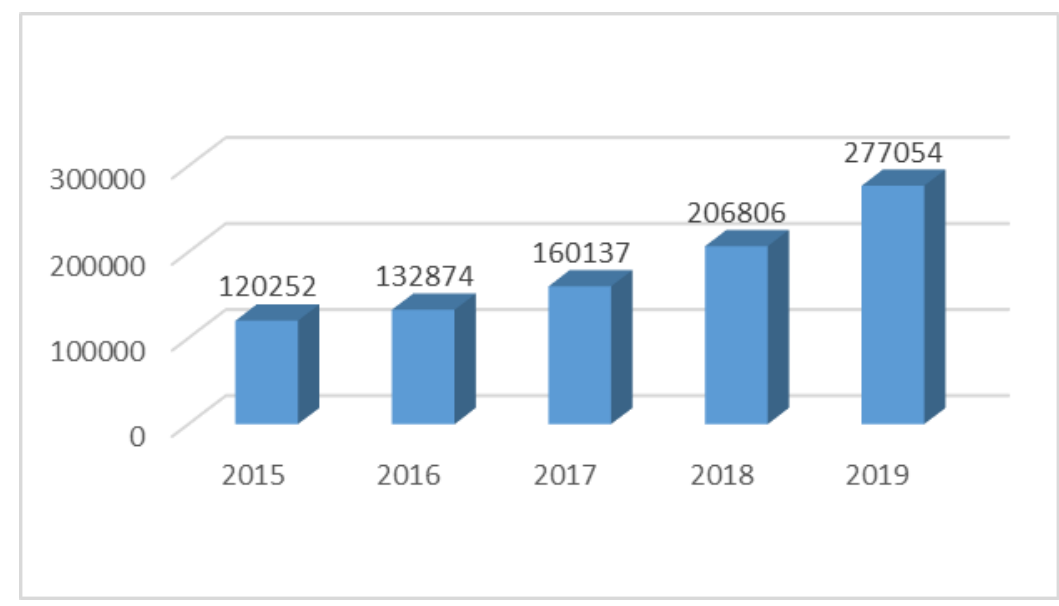

Şekil 1. Katılım Bankaları Toplam Aktif Gelişimi (2015-2020) (milyon TL)

Kaynak: TKBB, 2019 
Katılım bankalarının toplam net kârı aşağıdaki şekilde gösterilmektedir.

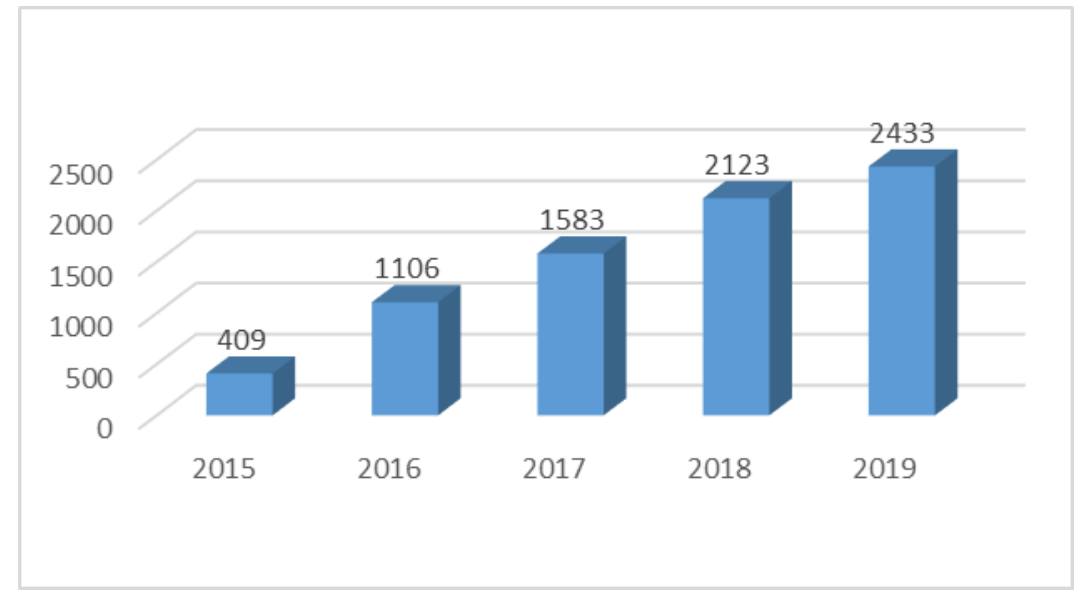

Şekil 2. Katılım Bankalarının Net Kâr Gelişimi (2015-2019) (milyon TL) Kaynak: TKBB, 2019

Bankalar açısından risk yönetimi büyük önem arz etmektedir. Risk; gerçekleşmesi beklenen ve düşünülen durum ile gerçekleşen durum arasındaki fark olarak tanımlanabilir. Riskin doğru ölçülmesi ve doğru risk yönetiminin kullanılması önemli olup, bankaların varlığını sürdürebilmesinin temel koşullarından birisi de etkin risk yönetim sistemine sahip olmaktır (Bağc1, 2018:78)

Finansal sistemin çok önemli bir unsuru olan bankacılık sisteminin etkin ve verimli bir biçimde faaliyetlerini sürdürmesi; fon fazlası olan tasarruf sahipleri, fon ihtiyacında bulunan kesim ve genel olarak ülke ekonomisinin tüm unsurları arasında mali hizmetlerin ve fon transferlerinin düzenli bir şekilde gerçekleşmesi açısından önemli görülmektedir (Samırkaş ve diğerleri, 2014:119).

\section{LITERATÜR TARAMASI}

Literatürde mevcut, bankaların kârlılık ve performanslarının analizi ile ilgili çalışmalardan bazıları aşağıda özetlenmiştir.

Parlakkaya ve Çürük (2011) Türkiye'de mevcut geleneksel bankalarla katılım bankalarının farklılıklarını ortaya koymak için yaptıkları çalışmada; kârlılık oranı ve likidite oranını bu iki tür bankanın ayırt edici bir unsuru olduğu öngörülerek gerçekleştirilen analizde t-testi ve logistik regresyon metodları kullanılmış olup konvansiyonel bankalar ve katılım bankalarının operasyonel faaliyetlerinin birbirinden farklı olduğu sonucuna ulaşılmıştır.

Gülhan ve Uzunlar (2011) tüm banka türleri için kârlılığın belirleyicilerini tespit etmek üzere yaptıkları regresyon tahmininin sonuçlarına göre; bankaların sermayesi ile kârlılıkları arasında uygulanan bütün modellerde pozitif ve anlamlı ilişki olduğu belirlenmiştir.

Doğan (2013), çalışmasında; 2005-2011 yılları arasında faaliyet gösteren katılım bankaları ve mevduat bankalarının finansal performanslarını karşılaştırarak banka türleri arasındaki farklılığı tespit etmek üzere t- testi uygulamıştır. Yapılan analiz neticesinde katılım 
bankalarının likidite oranı ve borç ödeme gücü düşük, riskliliği yüksek olmakla birlikte kârlılık yönünden geleneksel bankalarla anlamlı bir farklılık belirlenememiştir.

Pan ve Pan (2014), 2012 yılı dış faktörlerin Çin'in sermaye piyasasına getirebileceği olası etkilere ilişkin 1998 yılından itibaren Çin borsasında işlem gören 10 bankadan oluşan bir panel ile yapılan ve değişken olarak Gayri Safi Yurtiçi Hasıla (GSYİH), para arzı büyümesi, kredi faiz oranları, enflasyon oranları ve brüt hisse senedi fiyatlarının bankaların aktif kârlılığı üzerindeki etkisini incelemek üzerine oluşturulan regresyon modeli ampirik analiz sonucuna göre makro ekonomik unsurların kârlılık üzerinde belli ölçüde etkiye sahip olduğu bilgisi doğrulanmıştır.

Samırkaş ve diğerleri (2014) çalışmalarında; Ocak 2003-Haziran 2012 dönemi verilerine göre mevduat bankaların kârlılığını etkileyen faktörleri tespit etmek üzere bankaya özgü faktörler ile makro ekonomik faktörleri kullanmak suretiyle çoklu doğrusal regresyon analizi uygulamışlardır. Gerçekleştirilen analiz neticesinde bankaların aktif kârlılığı ve özkaynak kârlılığı oranlarının; faiz dışı gelirlerinin aktif toplamına oranından ve özkaynak/toplam aktif oranından pozitif etkilendiği belirlenmiştir. Ayrıca, mevduat faizi oranındaki artışın aktif kârlılığı negatif etkilediği tespit edilmiştir.

Tuzcu (2015) çalışmasında; Türkiye'de bankacılık sektörünün kârlılığını belirlemek üzere 30 bankanın verilerini dinamik panel veri yöntemi ile araştırmıştır. Sermaye ile kredi riski gibi içsel değişkenlerin kârlılık üzerinde önemli ölçüde etkili olduğu tespit edilmiştir.

Toraman ve diğerleri (2015) çalışmalarında; mevduat ve katılım bankalarının 20062014 yılları arasında mali tablo bilgilerine dayalı finansal oranlarını kullanarak gerçekleştirdiği t-Testi sonucunda, mevduat bankalarının toplam aktif ve likit aktif büyüklüklerinin katılım bankalarından daha yüksek olduğunu ve sermaye yeterliliği açısında mevduat bankalarının katılım bankalarından daha güçlü bir yapıya sahip olduğunu belirlemişlerdir.

Y1lmaz ve Demirhan (2016) Balkan ülkelerinin verilerini kullanarak beşerî sermayenin ekonomik büyüme üzerindeki etkisini uzun vadede ampirik olarak araştırmışlardır. Bu çalışmada, Ekonometrik tahminlerde panel eş bütünleşme tekniği ve Tam Değiştirilmiş En Küçük Kareler (FMOLS) ve Dinamik En Küçük Kareler (DOLS) yöntemleri kullanılmıştır. FMOLS tahminleri, yükseköğretime kayıt oranındaki bir puanlık ve sağlık harcamalarının GSYİH'ya oranındaki bir puanlık artışın, kişi başına reel GSYİH'yı sırasıyla yüzde 1,3 ve yüzde 9,9 oranında artırdığını göstermektedir. Ayrıca, sağlık harcamalarının GSYİH'ya oranındaki bir puanlık artışın kişi başına reel GSYİH'yı yüzde 13,1 oranında artırdığını göstermiştir. Modellerde beşeri sermayedeki artışın işgücü verimliliğini artırdığı sonucuna varılmıştır.

Reis ve diğerleri (2016) çalışmalarında; Türk bankacılık sektöründe kârlılığa etki eden faktörleri ortaya koymak üzere panel veri analizi uygulamışlardır. Araştırmada net faiz marjı ve aktif kârlılığı etkileyen içsel ve dışsal faktörler belirlenmeye çalışılmıştır. Bulgulara göre, kaldıraç oranının ve kredi/mevduat oranının aktif kârlılığı negatif yönde etkilediği, piyasa kapitalizasyonu ise pozitif yönde etkilediği tespit edilmiştir. Kârlılık konusunda oluşturulan diğer modelde bağımlı değişken olan net faiz marjının; kaldıraç oranı, kredi/mevduat oranı, 
piyasa kapitalizasyonu ve gayrisafi yurtiçi hasıla değişkenlerinden negatif yönde etkilendiği tespit edilmiştir.

Görüş ve Özgür (2016) yaptıkları çalışmada, Türkiye mevcut İslâmi bankaların kârlılığına etki eden banka içi faktörleri tespit etmek üzere En Küçük Kareler (EKK) metodu kullanarak uygulama gerçekleştirmişlerdir. Çalışmanın sonuçlarına göre; öz sermayenin toplam varlıklara oranı, net faiz marjı ve pazar payı faktörlerinin banka kârlılığı üzerindeki etkilerinin pozitif ve anlamlı olduğu, net faiz marjı değişkeninin katsayısı 0,432 olarak hesaplandığı ve banka kârlılığını etkileyen en güçlü banka içi faktör olduğu belirlenmiştir.

Karakuş ve Küçük (2016) çalışmalarında; mevcut katılım bankalarının kârlılığını etkileyen makroekonomik faktörler ile bankalara özgü içsel faktörlerin belirlenmesi için analiz gerçekleştirmişlerdir. Uygulamanın neticesinde, ABD doları efektif satış kuru, tüketici fiyat endeksi, gayri safi yurt içi hâsıla ve duran varlıkların aktif toplama oranı ile her iki kârlılık değişkeni arasında negatif yönlü, çalışan sayısı ile kârlılık göstergeleri arasında ise pozitif ilişki olduğu belirlenmiştir.

Kahveci vd. (2016) çalışmalarında, bankaların, sermaye yapısı değişikliklerinin, net faiz gelirleri üzerindeki etkilerini panel veri analizi ile incelemiş olup, çalışmada sonuç olarak bankaların net faiz gelirleri kriz yıllarında olumlu etkilendiği, özkaynakların net faiz getirisi ile pozitif ilişkisinin olduğu ve özkaynakların net faiz gelir üzerinde pozitif olarak \%5 seviyesinde anlamlı etkisinin olduğu bulunmuştur.

Saldanlı ve Aydın (2016) yapmış oldukları çalışmada bankaların 2004-2014 yı1ları arasında kârlılığına etki eden faktörleri tespit etmeye çalışmışlardır. Çalışmada uygulanan panel veri analizi sonucu itibariyle; faiz dışı gelirler(net)/ toplam aktif oranının bankaların aktif kârlılığı üzerinde \%99 güven aralığında, özsermaye kârlılığında ise \%95 güven aralığında istatistiki açıdan anlamlı olduğu tespit edilmiştir.

Şit ve Hacıevliyegil (2019), çalışmalarında, sermaye yeterlilik oranının banka kârlılıkları üzerinde etkisini araştırmak üzere, Türkiye'de bankacılık sektöründe aktif büyüklükleri itibariyle en büyük 10 banka ile (7'si özel, 3'ü kamu bankası) 3 katılım bankasının 2011-2016 çeyrek dönem verilerini kullanarak panel veri analizi uygulamışlardır. Analiz neticesinde, bankaların sermaye yeterliliklerinin kârlılıklarına etkisinin bulunduğu belirlenmiş ancak sermaye yeterliliğinin kârlılı̆̆a etkisi yönünden katılım bankaları ile konvansiyonel bankalar arasında farklılık belirlenmemiştir.

Aka (2019), çalışmasında katılım bankalarının kârlılığı ile ilgili aktif kârlılığı ve özsermaye kârlılığını bağımlı değişken olarak değerlendirmiş olup, kârlılığa etki eden faktörleri tespit etmek üzere bankaya özgü, sektöre özgü ve makroekonomik faktörleri bağımsız değişken olmak üzere panel veri analizi uygulamıştır. Analiz neticesinde, aktif büyüklük, kaldıraç oranı, takipteki kredilerin oranı, kredi mevduat oranı, operasyonel etkinlik ve banka piyasa yoğunluğu değişkenleri ile banka kârlılığı arasında istatistik yönünden anlamlı ilişki tespit edilmiştir.

Aydın (2019), çalışmasında Türk bankaların kârlılığına etki eden faktörleri; bankaya özgü, sektöre özgü ve makro ekonomik faktörler şeklinde modelleyerek panel veri analiz ile tahmin etmeye çalışmıştır. Araştırma neticesinde; kredi riski, banka büyüklügüu, faaliyet 
giderleri, banka sermayesi, faiz dişı gelirler ve ekonomik büyüme değişkenlerinin aktif kârlılığa istatistik olarak anlamlı etkiye sahip değişkenler olduğu belirlenmiştir. Özkaynak kârlılığı ile ilgili uygulama modelinde ise banka büyüklüğü, faaliyet giderleri, faiz gelirleri, faiz dış1 gelirler, enflasyon oranı ve sektörel yoğunlaşma gibi değişkenlerin istatistiksel olarak anlamlı etki eden faktörler olduğu belirlenmiştir.

Güler (2019), faaliyet bulunan üç katılım bankası ile aktif büyüklükleri itibariyle ilk dört mevduat bankasını, 2015-2018 yılları arasında toplam on dört çeyrek dönemi kapsayacak şekilde uygulama çalışması yapmıştır. Bu çalışmada öz kaynak kârlılığı ve aktif kârlılığı bağımlı değişken olarak kullanmıştır. Banka kârlılığını etkilediği öngörülen birçok sayıda içsel faktör bağımsız değişken modelde kullanılmıştır. Yapılan analiz uygulaması sonucuna göre, net faiz (kâr payı) faiz geliri (gideri)/toplam aktif oranı katılım bankalarında kârlılığı artırırken mevduat bankalarında kârlılığı azaltmakta olduğu tespit edilmiştir.

Chatterjee (2020), bilgi ve iletişim teknolojisi yayılımı ile ekonomik büyüme ilişkisini panel veri analizi yöntemiyle incelemiştir. Bu çalışma, 41 ülkenin sabit etkili panel veri modelini kullanarak bilgi işlem teknolojisinin gelişiminin finansal içerme için önemli bir belirleyici olabileceğini göstermiştir.

Bakkeri ve Ben Ali (2020), Orta Doğu ve Kuzey Afrika'da faaliyet gösteren 30 İslami bankanın 2005'ten 2018'e kadar olan bir dönemde iç ve dış faktörlerin kârlılık üzerindeki etkisini, panel verilerine göre OLS yöntemini kullanarak incelemişlerdir. Sonuçlar, yönetim kalitesi, likidite ve kapitalizasyon, hizmet kalitesi, kadınların varlığı ve personelin yetkinliğinin kârlılığın önemli belirleyicileri olduğunu göstermiştir. Çeşitlendirmenin, büyüklüğün ve enflasyonun İslami bankaların kârlılığı üzerinde önemli bir etkisinin olmadığ sonucuna ulaşılmıştır.

Linhartova (2021), AB-28 Ülkelerinde yaptığ1 panel veri analizinde kamu harcamalarının insani gelişmedeki rolünü incelemiştir. 1995-2018 döneminde 28 AB ülkesi örneklemi için panel veri analizi uygulanmıştır. Çalışmada harcamalarının insani gelişme üzerinde hem olumlu hem de olumsuz etkisi olduğu kanıtlanmıştır. Sabit etkili model ile panel veri analizi, kamu harcamalarının rekreasyon, kültür ve din üzerinde en yüksek olumlu etkiye sahip olduğunu göstermiştir.

Haralayya ve Aithal (2021), Hint bankacılık sektörünün performansını etkileyen faktörleri irdeledikleri çalışmalarında panel veri yöntemi kullanmışlardır. 2005-2020 döneminde Hindistan'da seçilen 18 kamu sektörü, 13 özel sektör ve 16 yabancı sektör bankalarının performansını etkileyen faktörler incelenmiştir. Bağımsız değişken olarak, sermaye yeterliliği rasyosu, net kâr, fon maliyetine göre düzeltilmiş yatırım getirisi, fon maliyetine göre düzeltilmiş avans getirisi, yatırım getirisi, yatırım mevduat oranı, kredi mevduat oranı, nakit - mevduat oranı, borçlanma ve çalışan başına kâr belirlenmiştir. Çalışmanın sonuçları, aktif kârlılığı ve özkaynak kârlılığının net kâr, fon maliyetine göre ayarlanmış avans getirisi, nakit mevduat oranı, toplam borçlanma ve çalışan başına kâr ile önemli ölçüde ilişkili olduğunu göstermiştir.

Jadah., Hasan ve Al-Husainy (2021), çalışmalarında Irak bankalarının sermaye yapısını 2005-2019 dönemi için dinamik panel GMM'i kullanarak incelemişlerdir. Çalışmanın belirleyici faktörleri; banka büyüklüğü, banka kârlılığı, banka büyümesi, 
somutluk, banka yaşı olarak belirlenmiştir. Bulgular, banka büyüklüğü, banka kârlılı̆̆ı ve banka yaşının baskın bir role sahip olduğunu göstermektedir.

Ramos ve Casado-Molina (2021) yapmış oldukları çalışma ile bankacılık sektöründeki şirketlerin online kurumsal itibarlarını bir panel veri yaklaşımı ile itibar endeksi oluşturulmasını önermiştir.

\section{ARAŞTIRMANIN AMACI VE KAPSAMI}

Katılım bankaları, Türkiye'de bankacılık sektöründe büyüyen kapasitesi ve gelişimi dolayısıyla finans sektöründe önemli bir yere sahiptir. Finans sektörü bütün halinde ülke ekonomisinin ana omurgasını oluşturması dolayısıyla sağlıklı işlemesi ve gelişmesi değerlidir. Bütün işletmelerde olduğu gibi bankacılık sektöründe de kârlılık banka hizmetlerinin sürdürülebilirliği açısından üzerinde durulması gereken bir konudur. Kârlılığın sağlanması ise; kârlılığa etki eden faktörlerde hem etkin kapasite kullanımının sağlanması, hem de verimli uygulamaların gerçekleştirilmesi ile mümkün görülmektedir. Kârlılığa etki eden faktörlerin tespit edilmesi sayesinde kaynakların etkin kullanılması ile verimli uygulamalarının gerçekleşmesi mümkün olacaktır.

Literatürde finansal performans göstergesi olmak üzere genelde aktif kârlılığın kullanıldı̆̆ı tespit edilmiştir. Bu yönde analiz uygulamasında bağımlı değişken olarak aktif kârlılığına etki eden faktörlerin belirlenmesi amaçlanmıştır. Bu çalışma literatürdeki diğer çalışmalardan, hem enflasyon oranı ve GSMH büyüme oranı gibi kullanılan dışsal bağımsız değişkenler hem de Türkiye'de faaliyette bulunan tüm katılım bankalarının çalışmaya dahil edilmesi yönüyle, farklılık arz etmektedir.

Araştırma çalışmasında örneklem olarak kullanılan katılım bankaları Tablo 1.'de gösterilmektedir.

Tablo 1. Araştırma Örneklemindeki Katılım Bankası Bilgileri

\begin{tabular}{|l|l|}
\hline Gösterim & Katılım Bankası \\
\hline 1 & AlbarakaTürk Katılım Bankası A.Ş. \\
\hline 2 & KuveytTürk Katılım Bankası A.Ş. \\
\hline 3 & Türkiye Finans Katılım Bankası A.Ş. \\
\hline 4 & Vakıf Katılım Bankası A.Ş. \\
\hline 5 & Ziraat Katılım Bankası A.Ş. \\
\hline
\end{tabular}

Türkiye'de mevcut son 2015-2019 yılları arasında faaliyette bulunmuş olan tüm katılım bankaları kapsam içinde değerlendirilmiştir. Vakıf Katılım Bankası ile Ziraat Katılım Bankası kuruluş tarihi 2015 yılı olması dolayısıyla başlangıç sınırı 2015 yılı olarak belirlenmiştir. Böylece panel veri analizine Türkiye'de mevcut 5 katılım bankası dahil edilmiştir. Panel veri setinde kullanılan her bir yatay kesit verisinin ele alınan zaman süresine ilişkin tüm verilerinin elde edilmiş olması durumuna dengeli panel denilmektedir. Araştırma kapsamındaki tüm katılım bankalarının 2015-2019 yılları arasındaki değişken olarak kullanılacak finansal verilerine ulaşılmış olması dolayısıyla dengeli panel gerçekleştirilmiştir. 
Araştırmada kullanılan veri kaynakları ise, dışsal değişkenler yönünden enflasyon oranı ve büyüme oranı TÜİK verilerine dayanmaktadır. Katılım bankalarının içsel değişkenlerine ilişkin veriler ise, ilgili katılım bankasının 2015, 2016, 2017, 2018 ve 2019 yılları itibariyle açıklanan faaliyet raporlarından elde edilen rakamlar olup, bu rakamlara katılım bankalarının resmi internet sayfalarından ulaşılmıştır.

\section{ARAŞTIRMANIN YÖNTEMİ VE MODELI}

Araştırma çalışmasında panel veri analizi kullanılacaktır. Panel veri analizi genel olarak bir regresyon modelidir. Klasik regresyon modellerinde kullanıldığı şekli ile bir bağımlı değişken ile bu bağımlı değişkenle ilgili bir veya birden fazla bağımsız değişken çözümleme için kullanılmaktadır. Modelde hata terimi de bulunabilmektedir. Modelde kullanılan değişkenler birime ve zamana göre etkili olabilmektedir (Taysı, 2020:21).

Panel veri modeli,

$$
Y=\alpha_{i t}+\beta_{i t} X_{i t}+u_{i t} \quad \mathrm{i}=1, \ldots \ldots, \mathrm{N} ; \mathrm{t}=1, \ldots \ldots, \mathrm{T}
$$

olarak ifade edilebilir. Formülde, Y: bağımlı değişken, X: bağımsız değişken, $\alpha$ sabit parametre, $\beta$ eğim parametresi ve $u$ hata terimidir. $i$ alt indisi birimleri (birey, firma, şehir, ülke gibi), $t$ alt indisi ise zamanı (gün, ay, yıl gibi) ifade etmektedir (Tatoğlu, 2020:7).

Panel data analizi yönetiminin birçok avantajı, yöntemin farklı farklı bilimsel amaçlar için kullanılmasını mümkün kılmıştır. Hsiao (2007) çalışmasında panel data analizi yönteminin avantajlarını ve üstünlüklerini şöyle sıralamıştır; (i) veri kullanılabilirliğinin yüksek olması, (ii) insan davranışının karmaşıklığını modellemek için tek bir kesit veya zaman serisi verisinin izin verebileceğinden daha fazla ve daha yüksek kapasite sağlaması (iii) gelişmiş bir metodoloji olması şeklinde. Baltagi'ye (2001) göre panel data yöntemi verilerin kesitsel ve zaman serisi özelliklerini dikkate alır ve değişkenlerde zaman içinde ve bir dizi ülke veya şirket olabilecek farklı birimler arasındaki değişiklikleri analiz etmeyi mümkün k1lar. Böylece zamansal ve kesitsel veriler arasındaki kurulan ilişki daha iyi tahminleri mümkün k1labilir. Çünkü, panel data, heterojenliğinin kontrolünü mümkün kılar, daha fazla bilgi, daha az doğrusallık ve daha fazla verimlilik sunar, uyum dinamiklerinin incelenmesine izin verir, etkileri belirlemede ve ölçmede çok daha iyi sonuçlar elde edilebilir.

Panel veri analizi, kesit analizi ile zaman serisi analizini birleştiren bir yöntemdir. Panel verinin karmaşık yapısı dolayısıyla çözümleme yapmak üzere bilgisayar ortamında geliştirilen paket programlar (Stata, Eviews, vb) bulunmaktadır (Er, 2009:48).

Panel veri metodolojisinde kullanılan üç model bulunmaktadır. Bunlar; klasik model, sabit etkiler modeli ve tesadüfi etkiler model şeklindedir. $\mathrm{Bu}$ modellerden hangisinin seçileceği hususunda karar verilirken belirli testler (Hausman, Breusch-Pagan Testi, Chow Testi, F testi) uygulanmaktadır. (Reis vd., 2016:29).

İstatistik uygulamaları ve veri analizlerinin temel amacı, değişkenler arasındaki ilişkileri ortaya koymak ve değişkenlerde ortaya çıkan farkın ne miktarda olduğu, hangi yönde değiştiği, neden etkilendiği gibi soruların cevabını bulmaktır. Ekonomik birimlerin 
eğilimlerini incelemede çok değişkenli istatistik yöntemlerinden yararlanılmaktadır. Çalışmada uygulanan model aşağıdaki gibidir;

$$
N A_{i t}=\alpha_{i t}+\beta_{i t} S Y_{i t}+\beta_{i t} K G_{i t}+\beta_{i t} K A_{i t}+\beta_{i t} E O_{i t}+\beta_{i t} B O_{i t}+u_{i t}
$$

Uygulama modelinde $\mathrm{i}=1, \ldots ., 5$ çalışma kapsamına alınan bankaları, $\mathrm{t}=2015, \ldots, 2019$ zamanı göstermektedir.

Araştırma çalışmasında katılım bankalarının kârlılığına etki eden içsel ve dışsal faktörler belirlenmeye çalışılmaktadır. Bu aşamada literatürdeki araştırmalarda kullanılmış bulunan aktif kârlılığı açıklamakta etkili olabileceği değerlendirilen içsel faktörlerle genel ekonomi ile ilgili durumu tespit etmek için uygun görülen dişsal faktörler değerlendirilmiştir. Yapılan tarama neticesinde bu çalışma için özgün değişken seti oluşturulmuştur. Çalışmanın analizinde kullanılacak değişkenler ve bu değişkenlere ilişkin kısaltmalar aşağıdaki tabloda belirtilmektedir.

Tablo 2. Bağımlı ve Bağımsız Değişken Seti

\begin{tabular}{|c|c|c|c|}
\hline Kısaltma & Değişken Açıklaması & Değişken Türü & $\begin{array}{c}\text { İçsel/Dışsal } \\
\text { Faktör } \\
\text { İçsel }\end{array}$ \\
\hline NA & Net Dönem Kârı (Zararı)/Toplam Aktifler & Bağımlı & İsel \\
\hline SY & Sermaye Yeterlilik Rasyosu & Bağımsız & İcsel \\
\hline KG & Kâr Payı Giderleri/Toplam Aktifler & Bağımsız & İçsel \\
\hline KA & Kullandırılan Fonlar/Toplam Aktifler & Bağımsız & Dışsal \\
\hline EO & Enflasyon Oranı & Bağımsız & Dışsal \\
\hline BO & GSMH Büyüme Oranı & Bağımsız & \multicolumn{2}{c}{} \\
\hline
\end{tabular}

Uygulama çalışmasında Net Dönem Kârı (Zararı)/Toplam Aktifler bağımlı değişken olarak belirlenmiştir. Katılım bankalarının kârlılığına etki eden içsel faktörler olarak; Sermaye Yeterlilik Rasyosu, Kâr Payı Giderleri/Toplam Aktifler ve Kullandırılan Fonlar/Toplam Aktifler seçilmiş olup, dişsal faktörler ise GSMH Büyüme Oranı ve Enflasyon Oranı şeklindedir. Katılım bankalarında aktif kârlılığına seçilen değişkenlerin etkili olabileceği düşünülmüştür.

Araştırma çalışmasında kullanılan veri seti literatürde çalışmalar incelenerek aktif kârlılık oranına etki eden faktörler değerlendirilmiş olup, bu çalışmaya özgü etki durumu yüksek oranlar kullanılmıştır. Başka çalışmalarda da kullanılan verilerin değerlendirilmesi karşılaştırma ve yorumlama açısından uygun görülmüştür. Veri setinin her bir değişkeni farklı çalışmalarda kullanılmakla birlikte bu çalışmada oluşturulan kompozisyon özgündür.

Değişkenler yönünden enflasyon oranı için Tüketici Fiyat Endeksi (TÜFE) kullanılmıştır. GSMH ve TÜFE değerleri TÜİK verilerine dayanmaktadır. Diğer değişkenlere ilişkin veriler ise ilgili katılım bankasının yıllar itibariyle açıklanan faaliyet raporlarından elde edilen rakamlardır. 


\section{BULGULAR}

Araştırmada faaliyette bulunan 6 katılım bankasından 5'i örneklem olarak alınmıştır. Yapılan model kapsamında toplam 25 gözlem ile analiz gerçekleştirilmiştir. Değişkenlerle ilgili tanımlayıcı istatistikler bilgisi Tablo 3 'te gösterilmektedir.

Tablo 3. Değişkenlerle İlgili Tanımlayıcı İstatistik Bilgisi

\begin{tabular}{|c|l|l|l|l|l|l|}
\hline Değişken & \multicolumn{1}{c|}{ NA } & \multicolumn{1}{c|}{ SY } & \multicolumn{1}{c|}{ KG } & \multicolumn{1}{c|}{ KA } & \multicolumn{1}{c|}{ EO } & \multicolumn{1}{c|}{ BO } \\
\hline Ortalama & 1.0164 & 16.8628 & 0.036192 & 0.6136 & 11.99 & 4.1 \\
\hline $\begin{array}{c}\text { Standart } \\
\text { Sapma }\end{array}$ & 1.177097 & 7.850536 & 0.0151648 & 0.1965299 & 3.28785 & 2.428134 \\
\hline Varyans & 1.385557 & 61.63092 & 0.00023 & 0.038624 & 10.80996 & 5.895833 \\
\hline Çarpıklık & 3.264434 & 2.222948 & -0.6316925 & -2.450762 & 0.2388485 & 0.1724398 \\
\hline Basıklık & 15.43341 & 11.14195 & 3.165342 & 8.366833 & 1.308414 & 1.610729 \\
\hline $\begin{array}{c}\text { Gözlem } \\
\text { Sayısı }\end{array}$ & 25 & 25 & 25 & 25 & 25 & 25 \\
\hline
\end{tabular}

Tablo 3'te verilen sonuçlara göre örneklemdeki katılım bankalarının ortalama aktif kârlılığının yaklaşık \%1,01 seviyesinde olduğu belirlenmiştir. Bağımsız değişken olarak değerlendirilen içsel faktörlerden sermaye yeterlilik oranı ortalaması ise \%16,86 düzeyinde gerçekleşmiştir. Kâr payı giderleri/toplam aktifler oranı ortalaması \%3 şeklinde oldukça düşük çıkmıştır. Kullandırılan fonlar/toplam aktifler \%61 şeklindedir. Bağımsız değişken olarak değerlendirilen dişsal faktörlerden enflasyon oranı ortalaması \%11,99 ve GSMH büyüme oranı ortalaması ise $\% 4,1$ şeklinde tespit edilmiştir.

Araştırmada panel veri analizi yapılmadan evvel belirtilen değişkenler arasında çoklu doğrusal bağlantı sorunu olup olmadığının belirlenmesine ihtiyaç bulunmaktadır. Değişkenler arasında yüksek oranda ilişkilerin olmasına çoklu doğrusal bağlantı adı verilmektedir. $\mathrm{Bu}$ durum regresyon analizlerinde uygun görülmeyen durumu göstermektedir. İki değişken arasındaki basit korelasyon katsayısının 0.80 ve üstü olmaması istenmektedir (Kasım, 2019:122). Panel veri analizine geçmeden önce kullanılan değişkenler arasında korelasyon analizi yapılmış olup Tablo 4'te korelasyon analizinden elde edilen katsayı verileri gösterilmektedir.

Tablo 4. Değişkenlere İlişkin Korelasyon Analizi

\begin{tabular}{|c|c|c|c|c|c|c|}
\hline & NA & SY & KG & KA & EO & BO \\
\hline NA & 1.0000 & & & & & \\
\hline SY & -0.6431 & 1.0000 & & & & \\
\hline KG & -0.2887 & -0.2785 & 1.0000 & & & \\
\hline KA & -0.3846 & -0.2938 & 0.6521 & 1.0000 & & \\
\hline EO & -0.1099 & -0.1476 & 0.7563 & 0.2210 & 1.0000 & \\
\hline BO & 0.1083 & 0.0146 & -0.4921 & -0.1160 & -0.5773 & 1.0000 \\
\hline
\end{tabular}


Analiz sonucuna göre değişkenler arasında 0,8 ve üzerinde herhangi bir basit korelasyona rastlanılmamıştır. $\mathrm{Bu}$ durumda değişkenler arasında çoklu doğrusal bağlantı sorunu bulunmamaktadır.

Zaman serisinin zaman içinde belli bir değere yaklaşmasına veya öngörülen değer çevresinde bulunmasına "durağanlık" denilmektedir. Zaman serisine ilişkin istatistiki analiz yapılmadan önce, o seri ile ilgili sürecin zaman içinde sabit olup olmadığının, bir başka ifade ile serinin durağan olup olmadığının tespit edilmesi gerekmektedir. (Tatoğlu, 2020:14).

Literatürde birimler arası korelasyonun olduğu ve olmadığı durumlar ile karşılaşılmaktadır. Korelasyonun olmadığ senaryo için geliştirilen testlere birinci nesil testler ve korelasyonun olduğu senaryo için geliştirilen testlere ise ikinci nesil testler denilmektedir (Güriş, 2015:204). Aşağıdaki tabloda sunulan test sonuçları değişkenlerin her birine ait kesit bağımlılık sonuçlarını göstermektedir.

Tablo 5. Birim Kök Testleri

\begin{tabular}{|c|c|c|c|c|c|}
\hline \multirow{3}{*}{ Değişken } & \multirow{3}{*}{$\begin{array}{c}\text { Pesaran } \\
(2004) \\
\text { CD Test }\end{array}$} & \multicolumn{2}{|c|}{ HT Birim Kök Testi } & \multicolumn{2}{|c|}{ Pesaran'ın CIPS Birim Kök Testi } \\
\hline & & & & Düzeyde & Birinci Fark \\
\hline & & Duzeyde & Birinci Fark & CIPS & CIPS \\
\hline NA & -0.58 & $-0.0726^{*}$ & & & \\
\hline SY & -0.53 & $-0.1260 *$ & & & \\
\hline KG & $6.78^{*}$ & & & $2.610^{* *}$ & \\
\hline KA & 0.81 & $0.0950^{* *}$ & & & \\
\hline EO & 7.07* & & & $2.610^{* *}$ & \\
\hline BO & 7.07* & & & $2.610^{* *}$ & \\
\hline
\end{tabular}

Birimler aras1 korelasyon (Pesaran CD Test) sonucu itibariyle KG, EO ve BO değişkenlerinde $\% 1$ anlamlı olma düzeyinde birimler arası korelasyon belirlenmiştir. Bu durumda birimler arası korelasyon tespit edilmeyen değişkenler olarak NA, SY ve KA'nın durağanlığının kontrol edilmesinde birinci nesil, birimler arası korelasyon tespit edilen değişkenler olarak KG, EO ve BO'nun durağanlığının belirlenmesinde ise ikinci nesil birim kök testleri tercih edilecektir. Çalışmamızda birinci nesil birim kök testlerinden HarrisTzavalis testi, ikinci nesil birim kök testi olarak da Pesaran's CIPS Testi kullanılmış̧ır. Harris-Tzavalis testi zaman boyutunun ( $\mathrm{t}$ ) sonlu olduğunu, birim boyutunun (n) ise sonsuza gittiğini varsaymaktadır. Bu da mikropanel çalışmalarında karşılaşılan bir durumdur. Bu testin hipotezi " $\mathrm{H}_{0}$ : Paneller birim kök içermektedir" şeklinde tanımlanırken Pesaran's CIPS testinin hipotezi " $\mathrm{H}_{0}: \beta \mathrm{i}=0$ for all $\mathrm{i}$ ” şeklinde tanımlanır (Taysı, 2020:22).

Çalışmada kullanılan serilerin sabitliğinin kontrolü için yararlanılan test sonuçlarına göre modeldeki tüm değişkenler durağandır, yani serilerde birim kök yoktur.

Serilerin birim kök içerip içermedikleri kontrol edildikten sonra analizin ikinci aşaması analizde kullanılacak panel veri analizi yönteminin belirlenmesidir. Panel veri analizinde kullanılan yöntemden (klasik, sabit ve tesadüfi) hangisinin araştırmanın modeline uygun olduğunu belirlemek için bazı testlerin sınanması gerekmektedir. Bunlar F testi, LM testi ve Hausman testidir. Aşağıdaki tabloda test istatistikleri belirtilmektedir. 
Tablo 6. F Testi ve LM Testi Sonuçları

\begin{tabular}{|l|c|c|c|c|}
\hline \multirow{2}{*}{} & \multicolumn{2}{|c|}{ F Testi } & \multicolumn{2}{c|}{ LM Testi } \\
\cline { 2 - 5 } & İstatistik & Olasılık & İstatistik & Olasılık \\
\hline $\mathrm{NA}_{\text {it }}$ & 3.74 & $0.0265^{* *}$ & 0.00 & 1.000 \\
\hline
\end{tabular}

*,**,*** sirasılyla $\% 1, \% 5$ ve $\% 10$ düzeyinde anlamlı olma durumunu göstermektedir

Tablo 6'da yer alan F testi ve LM testi istatistiklerine göre yalnızca LM testi olasılık değerinin 0.05 'ten büyük olduğu görülmektedir.

Bu durumda yalnızca $\mathrm{LM}$ testi için " $\mathrm{H}_{0}$ : birim ve zaman etkisi yoktur" hipotezi kabul edildiğinden $\mathrm{F}$ testi sonucuna göre sabit etkiler modelinin, LM testi sonucuna göre ise klasik modelin kullanılması uygun bulunmuştur (Taysı, 2020:23). Bu durumda verilerin analizinde sabit etkiler modeli kullanılmıştır.

Kullanılan modelde değişen varyans, otokorelasyon ve birimler arası korelasyon bulunup bulunmadığını belirlemek amacıyla sırası ile Wald Testi, Baltagi Wu \& Bhargava Frenzini ve Narandranathan Testi ve Friedman'ın Testi uygulanmıştır. Yapılan bu testlerin sonuçlar Tablo 7’de gösterilmektedir.

Tablo 7. Modele İlişkin Varsayım Testleri

\begin{tabular}{|c|c|c|c|c|c|c|}
\hline & \multicolumn{2}{|c|}{ Değişen Varyans } & \multicolumn{2}{|c|}{ Otokorelasyon } & \multicolumn{2}{|c|}{$\begin{array}{c}\text { Birimler Arası } \\
\text { Korelasyon }\end{array}$} \\
\hline & İstatistik & Olasılık & $\begin{array}{l}\text { Durbin } \\
\text { Watson }\end{array}$ & BaltagiWU & İstatistik & Olasılık \\
\hline $\mathrm{NA}_{\mathrm{it}}$ & 39.17 & $0.000^{*}$ & 1.15 & 1.68 & 10.63 & 0.386 \\
\hline
\end{tabular}

Tablo 7'de yer alan varsayım testlerine göre uygulanan modelde değișen varyans ve otokorelasyon olduğu görülmekle birlikte birimler arası korelasyon yoktur. Bu durumu göz önünde bulundurarak tahmin yapmak üzere Arellano, Froot ve Rogers dirençli tahmincinden yararlanılmıştır ve elde edilen test sonuçları Tablo 8'de yer almaktadır.

Tablo 8. Katılım Bankalarında Kârlılığa Etki Eden Faktörlerin İncelendiği Panel Veri Analizi Sonuçları

\begin{tabular}{|c|c|c|c|c|}
\hline Değişkenler & Katsaylar & Standart Hata & T İstatistik & Olasılık (Prob) \\
\hline SY & $\mathbf{- 0 . 1 3 0 2}$ & $\mathbf{0 . 0 0 6 8}$ & $\mathbf{- 1 9 . 0 1}$ & $\mathbf{0 . 0 0 0}$ \\
\hline KG & -10.4564 & 19.0460 & -0.55 & 0.612 \\
\hline KA & $\mathbf{- 2 . 9 1 2 9}$ & $\mathbf{0 . 5 3 2 5}$ & -5.47 & $\mathbf{0 . 0 0 5}$ \\
\hline EO & -0.0449 & 0.0723 & -0.62 & 0.568 \\
\hline BO & -0.0008 & 0.0552 & -0.01 & 0.989 \\
\hline C & 5.3811 & 0.7872 & 6.84 & 0.002 \\
\hline $\mathrm{R}^{2}$ & 0.86 & & & 0.000 \\
\hline F İstatistik & 627.32 & Olas1lik (Prob) & \\
\hline$* * * * *$ sirasiyla $\% 1, \% 5$ ve $\% 10$ düzeyinde anlaml olma durumunu göstermektedir
\end{tabular}

Katılım bankalarında aktif kârlılığa etki eden faktörlerin incelendiği yukarıdaki analiz sonuçları incelendiğinde, modelin bağımsız değişkeni açıklama oranının \%86 düzeyinde olduğu belirlenmiştir. Oranın yüksek olması, modelin oluşturulması aşamasında doğru bağımsız değişkenlerin tercih edildiğinin bir göstergesi olarak değerlendirilebilir. Bağımsız 
değişkenlerden SY ve KA'nın bağımlı değişken üzerinde \%1 düzeyinde istatistik yönünden anlamlı olduğu ve negatif etkide bulunduğu belirlenmiştir. Bu etki sayısal olarak "SY'nin bir birimlik artışı, bağımlı değişkeni 0,13 birim, KA'nın bir birimlik artışı ise bağımlı değiş̧keni 2,91 birim azaltmaktadır" şeklinde yorumlanabilir. Diğer bağımsız değişkenler KG, EO ve BO'nun bağımlı değişkene istatistiksel olarak anlamlı etkisinin bulunmadığı belirlenmiştir.

Sabit etkiler modeli Arellano, Froot ve Rogers dirençli tahmincinden yararlanılarak elde edilen panel veri analiz sonuçları literatürde mevcut çalışmaların sonuçları ile karşılaştırıldığında:

Sermaye yeterlilik oranı değişkeni açısından; Güler (2019) çalışmasında bu çalışmaya benzer şekilde kârlılığa negatif etkili olduğunu belirlerken, Şit ve Hacievliyegil (2019) bu çalışmadan farklı olarak pozitif etkili olduğunu belirlemiştir.

- Kâr Payı Giderleri/Toplam Aktifler oranı değişkeni açısından; Görüş ve Özgür (2016) çalışmasında bu çalışmaya benzer şekilde istatistiksel olarak anlamlı olmadığı sonucuna ulaşmışıtır.

Kullandırılan Fonlar/Toplam Aktifler oranı değişkeni açısından, Güler (2019) çalışmasında bu çalışmadan farklı olarak kârlılık üzerinde anlamlı bir etkiye sahip olmadığını tespit etmiştir.

Enflasyon oranı değişkeni açısından; bu çalışma ile farklı olmak üzere; Gülhan ve Uzunlar (2011) çalışmasında 2002-2008 tüm bankalar ve yabancı bankalar modelinde ilişkinin negatif olduğu belirlenmiş, tüm banka modelinde ilişkinin anlamlı bulunmadığı, yerel bankalar modelinde ise ilişki pozitif ve anlamlı olduğu tespit edilmiştir. Ayrıca, 19902000 döneminde tüm modeller için pozitif ve anlamlı olduğu tespit edilmiştir. Pan ve Pan (2014) çalışmasında pozitif ve anlamlı ilişki belirlemiştir. Karakuş ve Küçük (2016) çalışmasında anlamlı ancak negatif yönde etkilendiğ̣i belirlenmiştir. Aydın (2019) çalışmasında ise pozitif ve anlamlı ilişki tespit edilmiştir.

GSMH büyüme oranı değişkeni açısından; Reis ve diğerleri (2016) çalışmasında bu çalışmaya benzer olarak istatistik yönünden anlamlı etkisi bulunmadığı belirlenmiştir. Ancak Gülhan ve Uzunlar (2011) çalışmasında farklı dönemlerde değişik durumlar söz konusu olduğu, 2002-2008 döneminde tüm bankalar ve yerel bankalar modelinde pozitif ve anlamlı bir ilişki bulunmakta iken yabancı bankaların yer aldığı modelde negatif ve anlamsız olduğu, 1990-2000 dönemine bakıldığında bu değiş̧ken yalnızca yerel bankalar için pozitif ve anlamlı olduğu tespit edilmiştir. Pan ve Pan (2014) çalışmasında pozitif ve anlamlı ilişki belirlemiştir. Karakuş ve Küçük (2016) çalışmasında anlamlı ve negatif yönde etkili olduğu belirlenmiştir. Aydın (2019) çalışmasında ise pozitif ve anlamlı ilişki tespit edilmiştir.

\section{SONUÇ}

Katılım bankacılığı Türkiye uygulamasının temeli 1970'li yıllarda dünyada yaşanan petrol krizi sonrasinda petrol üreticisi İslâm ülkelerinde toplanan büyük miktarda döviz rezervlerinin faizsiz bankacılık uygulaması ile ülkeye çekilmesine dayanmaktadır. Katılım bankacıllğı geçen yaklaşık 36 yılın sonunda önemli bir birikime sahip olarak bankacılık sektörünün \%8'ini kapsamaktadır.

Kârlılık tüm işletmeler açısından önemli bir performans göstergesidir. Kârlılığı tespit etmede genellikle aktif kârlılık değerlendirilmektedir. Bu çalışmada katılım bankacılığında 
aktif kârlılığı etkileyen içsel ve dışsal faktörler ve etki durumu araştırılmıştır. Türkiye'de mevcut 2015-2019 yılları arasında faaliyette bulunmuş olan tüm katılım bankaları kapsam içinde değerlendirilmiştir.

Araştırma uygulaması için panel veri analizi kullanılmıştır. Araştırma çalışması kapsamında panel veri analizi için bağımlı ve bağımsız değişkenler seçilerek model oluşturulmuştur. Çalışmada ilk olarak doğrusal bağlantı sorunu olup olmadığını tespit etmek için korelasyon analizi ve serilerin durağanlığını test etmek amacıyla da birim kök analizi yapılmıştır. Tercih edilecek tahmincinin belirlenmesi için F testi ve LM testleri yapılmış, elde edilen sonuçlara göre analize sabit etkiler modeli ile devam edilmiştir. Modeldeki temel varsayımlar incelendiğinde, modelde değişen varyans ve otokorelasyon problemlerinin olduğu tespit edilmiştir ve bu sorunları göz önünde bulundurarak tahmin yapabilen Arellano, Froot ve Rogers dirençli tahmincinden yararlanılmıştır. Elde edilen analiz bulgularına göre bağımsız değişkenlerden SY ve KA bağımlı değişkeni \%1 seviyesinde istatistik yönden anlamlı ve negatif etkide bulunmaktadır. Bu etki sayısal olarak 'SY'nin bir birimlik artışı, bağımlı değişkeni 0,13 birim, KA'nın bir birimlik artışı ise bağımlı değişkeni 2,91 birim azaltmaktadır" şeklinde ifade edilebilmektedir. Diğer bağımsız değişkenler KG, EO ve BO'nun bağımlı değişken üzerinde istatistiksel olarak anlamlı etkisi bulunamamıştır.

Elde edilen sonuç itibariyle katılım bankalarında sermaye yeterlilik oranında bir birimlik artış, aktif kârlılığı \%13 oranında azaltmakta, kullandırılan fonlar/toplam aktifler oranında bir birimlik artış ise aktif kârlılığ \% 291 oranında azaltmaktadır. Bu durum sonuç olarak, banka açısından kâr, üretilen hizmet ile ilgili olarak artmakta olup, sermaye yeterlilik oranının aktif kârlılığa negatif yönlü etkisinin olması risk unsurlarının minimize edilmesi ihtiyacı dolayısıyla bu durumun kârlılığa olumsuz etki etmiş olabileceği şeklinde yorumlanabilir. Öte yandan kullandırılan fonlar/toplam aktifler oranının katılım bankalarında kârlılığa negatif yönde yansıması ise; katılım bankalarının fon kullandırma oranında artış ile takipteki kredilerin artışı söz konusu olabileceği bunun da kârlılığa olumsuz etki etmiş olabileceği, ayrıca fon kullandırma haricinde bankacılık hizmetlerinden elde edilen gelirlerin kârlılığa marjinal etkisinin yüksek olabileceği şeklinde yorumlanabilir.

Literatürde çalışmalarda elde edilen bulgular yönünden ele alındığında; sermaye yeterlilik oranı değişkeni bir çalışmada bu çalışmaya benzer şekilde kârlılığa negatif etkili olduğu belirlenirken, başka bir çalışmada bu çalışmadan farklı olarak pozitif etkili olduğu tespit edilmiştir. Değişken ile ilgili farklı bulgular söz konusu olabilmektedir. Kâr pay1 giderleri/toplam aktifler oranı değişkeni ile ilgili ise, bir çalışmada bu çalışma ile benzer şekilde istatistiksel olarak anlamlı olmadığı sonucuna ulaşmıştır. GSMH büyüme oranı değişkeni açısından bir çalışmada bu çalışmaya benzer olarak istatistik yönünden anlamlı etkisi bulunmadığı belirlenmiş başka bazı çalışmalarda anlamlı ve negatif yönde etkili veya pozitif ve anlamlı ilişki tespit edilmiştir. Genel olarak değerlendirildiğinde literatürde erişilen çalışmalarda farklı dönemlerde farklı neticeler elde edildiği, açıklanan bazı faktörler yönünden bu çalışmayı destekler nitelikte olduğu anlaşılmıştır.

Literatürde banka kârlılığına etki eden faktörlere ilişkin çok sayıda çalışma mevcut olmakla birlikte bu çalışma diğer çalışmalardan içsel ve dışsal faktör seti itibariyle farklılık arz etmektedir. Ayrıca bu araştırma çalışmasının uygulaması yapılan zaman dilimi itibariyle de farklıdır. Bir başka konu ise bu çalışmada kullanılan veriler tüm dünyayı etkileyen Covid19 pandemi süreci öncesini kapsamakta olduğu dolayısıyla pandemi süreci ve pandemi süreci 
atlatıldıktan sonraki dönemlere ilişkin yapılacak çalışmalarla dönemsel karşılaştırma yapılması değerlendirilebilir. Böylece Covid-19 pandemi etkisi ile ilgili elde edilecek bulgulara göre dönemsel yorumlama gerçekleştirilebilir. Ayrıca kârlılığa etki eden faktörlerin belirlenmesi yönüyle araştırmacılar açısından ilerleyen süreçte etki etmesi muhtemel başka içsel, dışsal ve sektörel faktörlerin etkisine ilişkin uygulama yapılması öngörülmektedir.

\section{KAYNAKLAR}

Aka, Kemal (2019), "Banka Karlılığının Belirleyicileri: Türk Bankacılık Sektöründeki Katılım Bankaları Üzerine Ampirik Bir Uygulama”, Sosyal Bilimler Araştırma Dergisi, 8 (3), ss.21-39.

AlbarakaTürk Katılım Bankası A.Ş. $\quad$ Faaliyet Raporları, https://www.albaraka.com.tr/tr/yatirimci-iliskileri/finansal-bilgiler/faaliyet-raporlari, $(04 / 04 / 2021)$

Alpun, Mevlüde Elif (2017), Bankacılık Sistemi İçerisinde Katilim Bankacılığının Yeri ve Katilim Bankacılığının Güçlü ve Zayıf Yönleri, Yayınlanmamış Yüksek Lisans Tezi, Başkent Üniversitesi Sosyal Bilimler Enstitüsü Bankacılık Anabilim Dalı, Ankara

Aydın, Yüksel (2019), “Türk Bankacılık Sektöründe Karlılığı Etkileyen Faktörlerin Panel Veri Analizi ile İncelenmesi”, Gümüşhane Üniversitesi Sosyal Bilimler Enstitüsü Elektronik Dergisi, 10 (1), ss.181-189

Bağcı, Haşim (2018), “Gri İlişkisel Analiz Tekniği Kullanılarak Katılım Bankalarının Risk Düzeylerinin Karşılaştırılmasıı", I. Uluslararası Sigortacılık, Bankacılık ve Finans Sempozyumu İİBF 2018 Katılım Finansın Ekonomi Politiği Bildiri Özet Kitapçı̆̆ı

Baltagi, Badi H. (2001), Econometric Analysis of Panel Data (2nd Edition). West Sussex: Wiley and Sons.

Bakkeri, Amine - Ben Ali, Abdelhakim (2020) "Profitability of Islamic Banks: A Panel Data Analysis” Indian Journal of Finance and Banking. 4 (3), ss. 26-38

Chatterjee, Amrita (2020) "Financial Inclusion, Information and Communication Technology Diffusion, and Economic Growth: A Panel Data Analysis” Information Technology For Development, 26 (3), ss. 607-635

Doğan, Mesut (2013), “Katılım ve Geleneksel Bankaların Finansal Performanslarının Karşılaştırılması: Türkiye Örneğì”, Muhasebe ve Finansman Dergisi, (58), ss.175-188.

Er, Şebnem (2009), "Dinamik Panel Veri Analizi ve Bir Uygulama”, Yayınlanmıș Doktora Tezi, İstanbul Üniversitesi Sosyal Bilimler Enstitüsü İşletme Anabilim Dalı, İstanbul

Erdaş, Mehmet Levent (2015), “Katılım Bankalarının Kâr Dağıtım Metodları ve Bankacılık Sektöründeki Yapısal Analizi”, Sakarya University The Institute of Social Sciences, Departments of Islamic Economics and Finance Research Center for Islamic Economics and Finance International Congress on Islamic Economics and Finance (ICISEF) 21-23 October, 2015, Sakarya / Turkey, ss.111-133 
Esmer, Yusuf - Bağcı, Haşim (2016), "Katılım Bankalarında Finansal Performans Analizi: Türkiye Örneği”, Mehmet Akif Ersoy Üniversitesi Sosyal Bilimler Enstitüsü Dergisi Cilt.8 Say1.15 2016 - Haziran, ss. 17-30

Görüş, Muhammed Şehid - Özgür, Önder (2016), “Türkiye'de İslami Bankaların Karlılığının Belirleyicileri: Banka İçi Faktör Analizi”, Sakarya İktisat Dergisi, Haziran, 5 / 2, ss.113.

Güler, Sevda (2019), "Banka Kârlılık Oranlarının Panel Veri Analizi ile Değerlendirilmesi: Türkiye'de Faaliyet Gösteren Mevduat ve Katılım Bankalarının Karşılaştırılması", İzmir Democracy University Social Sciences Journal, 2 (2), ss.173-190.

Gülhan, Ünal - Uzunlar, Evcan (2011), "Bankacıllk Sektöründe Kârlılığı Etkileyen Faktörler: Türk Bankacılık Sektörüne Yönelik Bir Uygulama”, Atatürk Üniversitesi Sosyal Bilimler Enstitüsü Dergisi, 15(1). ss.341-368

Güriş, Selahattin (2015), Panel Veri Modelleri, Der Yayınları, İstanbul.

Haralayya, Bhadrappa - Aithal, Sreeramana (2021), "Performance Affecting Factors of Indian Banking Sector: an Empirical Analysis”, George Washington International Law Review, 7 (1). ss 607-621

Hsiao, Cheng (2007) "Panel Data Analysis-Advantages and Challenges" Sociedad de Estadística e Investigación Operativa, 16. ss. 1-22.

Jadah, Hamid Mohsin - Hasan, Mohammed Faez - Al-Husainy, Noor Hashim Mohammed (2021) "Dynamic Panel Data Analysis of Capital Structure Determinants: Evidence from Iraqi Banks” Journal of Business Strategy, Finance and Management, 2 (1\&2), ss. $102-114$.

Kahveci, Eyüp- Ekşi, İbrahim Halil - Kaya, Zekayi, (2016), “Türkiye’deki Mevduat Bankalarında Sermaye Yapıs1- Kârlılık İlişkisi: 2002-2014 Yılları Arası Panel Veri Uygulama”, Kastamonu Üniversitesi İktisadi ve İdari Bilimler Fakültesi Dergisi, 12, ss.446-461.

Karakuş, Rıfat, - Küçük, Şeyma Yılmaz (2016), "Katılım Bankalarında Kârlılığın Belirleyicileri: Türkiye Örneği İçin Bir Panel Veri Analizi" Ömer Halisdemir Üniversitesi İktisadi ve İdari Bilimler Fakültesi Dergisi, 9(2), ss.119-133.

Kasım, Muhammed (2019), İslâm İşbirliği Teşkilatı Ülkelerinde Sermaye Piyasalarının Gelişmişliğini Etkileyen Faktörlerin Panel Veri Analizi İle İncelenmesi, Yayınlanmamış Yüksek Lisans Tezi, Süleyman Demirel Üniversitesi Sosyal Bilimleri Enstitüsü, Isparta

KuveytTürk Katılım Bankası A.Ş. Faaliyet Raporları, https://www.kuveytturk.com.tr/yatirimci-iliskileri/finansal-bilgiler/yillik-ve-aradonem-faaliyet-raporlari, (04/04/2021) 
Linhartova, Veronika (2021), "Analyzing the Role of Public Expenditures in Human Development: Panel Data Analysis of EU-28 Countries”, Montenegrin Journal of Economics, 17 (1), ss 85-96.

Özgür, Ersan (2007), Katılım Bankalarının Finansal Etkinliği ve Mevduat Bankaları İle Rekabet Edebilirliği, Yayınlanmamış Doktora Tezi, Afyonkarahisar Kocatepe Üniversitesi Sosyal Bilimler Enstitüsü, İşletme Anabilir Dalı, Afyonkarahisar

Pan, Qinhua - Pan, Meiling (2014), "The Impact of Macro Factors on the Profitability of China's Commercial Banks in the Decade after WTO Accession”, Open Journal of Social Sciences, 2, pp.64-69

Parlakkaya, Raif - Çürük, Suna Akten (2011), "Finansal Rasyoların Katılım Bankaları ve Geleneksel Bankalar Arasında Bir Tasnif Aracı Olarak Kullanımı: Türkiye Örneği”, Ege Akademik Bakış, 11(3), ss.397-405.

Ramos, Célia M.Q. - Casado-Molina, Ana-María (2021). “Online Corporate Reputation: A Panel Data Approach And A Reputation İndex Proposal Applied To The Banking Sector” Journal of Business Research. 122, ss 121-130.

Reis, Şükriye Gül - K1lıç Yunus - Buğan Mehmet Fatih (2016), "Banka Kârlılığını Etkileyen Faktörler: Türkiye Örneği”, Muhasebe ve Finansman Dergisi Ekim/2016, 72(72), ss.21-36

Saldanlı, Arif - Aydın, Mücahit (2016), "Bankacılık Sektöründe Kârlılığı Etkileyen Faktörlerin Panel Veri Analizi ile İncelenmesi: Türkiye Örneği”, İstanbul Üniversitesi İktisat Fakültesi Ekonometri ve İstatistik Dergisi, (24), ss.1-9

Samırkaş, Mustafa Can - Evci, Samet - Ergün, Bahadır (2014), “Türk Bankacılık Sektöründe Kârlılığın Belirleyicileri”. Kafkas Üniversitesi İktisadi ve İdari Bilimler Fakültesi Dergisi, 5(8), ss.117-134.

Tatoğlu, Ferda $\quad$ Yerdelen (2020), Panel Veri Analizi, http://auzefkitap.istanbul.edu.tr/kitap/ekonometri_ue/panelverianalizi.pdf (15/12/2020)

Taysı, Kemal (2020), “Aktif Kârlılığa Etki Eden Faktörlerin Panel Veri Analizi Yöntemiyle Belirlenmesi”, Journal of Original Studies, 1(1), pp.15-30

Toraman, Cengiz - Ata, H. Ali - Buğan, Mehmet Fatih (2015), "Mevduat ve Katılım Bankalarının Karşılaşıırmalı Performans Analizi”. Cumhuriyet Üniversitesi İktisadi ve İdari Bilimler Dergisi, 16(2), ss.301-310.

Tuzcu, Sevgi Eda (2015), "The Effect of Derivatives Activity on Bank Profitability Before and During the Subprime Mortgage Crisis: Evidence from Turkey", Ankara Üniversitesi Sosyal Bilimler Dergisi, 6(1) 2015, pp.29-56.

Türkiye Finans Katılım Bankası A.Ş. Faaliyet Raporları, https://www.turkiyefinans.com.tr/trtr/yatirimci-iliskileri/finansal-raporlar/sayfalar/faaliyet-raporlari.aspx, (04/04/2021) 
TKBB, (2019), "Katıllm Bankaları $2019 \quad$ Raporu”, https://tkbb.org.tr/Documents/Yonetmelikler/Katilim-Bankalari-2019.pdf (04/02/2021)

TKBB, (2021), "Katılım Bankacıllı̆ı Nedir? Nasıl Çalışır?", https://tkbb.org.tr/Documents/Yonetmelikler/TKBB-Katilim-Bankaciligi-NedirBrosur.pdf (06/02/2021)

Vakıf Katılım Bankası A.Ş. Faaliyet Raporları, https://www.vakifkatilim.com.tr/tr/yatirimciiliskileri/faaliyet-raporlari, (04/04/2021)

Yllmaz, Cengiz - Demirhan, Banu (2016) "Long-term Impact of Human Capital on Economic Growth: A Panel Data Analysis on the Balkan Countries" British Journal of Economics, Management \& Trade 13(1): 1-12.

Ziraat Katılım Bankası A.Ș. Faaliyet Raporları, https://www.ziraatkatilim.com.tr/yatirimciiliskileri/finansal-bilgileri, (04/04/2021). 
